\title{
An Update on the Occurrence and Damage Caused to Cashew by Gypona cerea DeLong \& Freytag (Hemiptera: Cicadellidae) in Northeastern Brazil
}

\author{
SUYANNE A. DE SOUZA ${ }^{1}$, NIVIA S. DIAS-PINI ${ }^{1}$, LUIZ AUGUSTO L. SERRANO ${ }^{1}$, FRANCISCO C. VIDAL \\ NETO ${ }^{1}$, GABRIELA PRISCILA S. MACIEL ${ }^{1}$, VIVIANE R. DE SOUSA ${ }^{2}$ and WILSON S. DE AZEVEDO FILHO ${ }^{3}$ \\ ${ }^{1}$ Embrapa Agroindústria Tropical, Rua Dra. Sara Mesquita, 2270- Pici 60511-110, Fortaleza, Ceará, Brazil \\ ${ }^{2}$ Museu Nacional, Universidade Federal do Rio de Janeiro, Quinta da Boa Vista, \\ São Cristóvão, 20940-040 Rio de Janeiro, RJ, Brazil \\ ${ }^{3}$ Universidade de Caxias do Sul, Alameda João Dal Sasso, Universitário, 95705-266 Bento Gonçalves, RS, Brazil \\ Manuscript received on July 23, 2019; accepted for publication on September 24, 2019
}

\begin{abstract}
How to cite: SOUZA SA, DIAS-PINI NS, SERRANO LAL, VIDAL NETO FC, MACIEL GPS, SOUSA VR AND AZEVEDO FILHO WS. 2019. An Update on the Occurrence and Damage Caused to Cashew by Gypona cerea DeLong \& Freytag (Hemiptera: Cicadellidae) in Northeastern Brazil. An Acad Bras Cienc 91: e20190806. DOI 10.1590/00013765201920190806.
\end{abstract}

\begin{abstract}
We have identified specimens of the leafhopper Gypona cerea DeLong \& Freytag (Cicadellidae: Iassinae: Gyponini) collected from a crop of dwarf cashew (Anacardium occidentale Linnaeus 1753) located in Canto do Buriti, Piauí, Northeastern Brazil. The damage caused to the crop included inflorescences covered with sticky exudates, presence of sooty mold, and yellowing and drying of new shoots and inflorescences. Such documentation serves as a warning about possible outbreaks of infestation in the region and the likelihood of its expansion to other cashew producing areas.
\end{abstract}

Key words: Anacardium occidentale, Inflorescence Leafhopper, Insect Pest, New record.

\section{INTRODUCTION}

Cashew, Anacardium occidentale Linnaeus 1753 (Anacardiaceae), is a tropical plant that is both native to Brazil and of considerable economic and social importance to the country, especially in the northeastern region (Paiva et al. 2009, Serrano and Oliveira 2013). The principal producers of cashew nuts are the State of Ceará, which accounts for more than $50 \%$ of the total national production, followed by Piauí, Rio Grande do Norte, Bahia, Maranhão and Pernambuco (Instituto Brasileiro de Geografia e Estatística 2016). Since a diverse range

Correspondence to: Nívia da Silva Dias-Pini

E-mail: nivia.dias@embrapa.br

ORCid: https://orcid.org/0000-0002-3664-812X of insects is known to attack cashew, up-to-date information on the occurrence of phytophagous insects associated with the culture is of paramount importance in planning appropriate management and control measures.

The family Cicadellidae (Hemiptera) includes numerous species of leafhoppers, known in Brazil as "cigarrinhas", that may be up to $18 \mathrm{~mm}$ in length and present posterior tibiae with one or more rows of movable small spines (Marucci et al. 2002). The immature and adult forms of these insects feed from the same food niche by sucking sap from the roots and aerial parts of plants (Marques 2011). The host preference for oviposition and nymph development varies according to the species of leafhopper and is not necessarily limited to a single plant species. 
Gyponini is the largest tribe of the subfamily Iassinae, being restricted to the Neotropical and Nearctic regions (Nielson 1985, Nielson and Knight 2000). The tribe includes species, such as those of the genus Gypona Germar, that not only cause serious mechanical damage to plants through the sucking mouthparts but can also transmit phytopathogens (Harris and Maramorosch 1980, Maramorosch and Harris 1981, Nielson 1968, 1985). Leafhoppers belonging to this group present large variations regarding size and color, but all are relatively robust and slightly flat (Triplehorn and Johnson 2011).

In view of the agricultural importance of Gypona species, our aim was to establish the occurrence and damage caused by this leafhopper to dwarf cashew crops in the State of Piauí. Documentation of the occurrence of this leafhopper in Piauí is essential in establishing trends in range expansion and in devising control strategies.

\section{MATERIALS AND METHODS}

Leafhoppers were observed on branches and inflorescences of two different dwarf cashew genotypes, namely CCP76 and BRS226 (Vidal Neto et al. 2013), cultivated at "Fazenda Santa Fé" located in "Canto do Buriti", Piauí, Brazil (08 ${ }^{\circ} 06^{\prime}$ 36” S, $422^{\circ} 56$ ' 40” W; 269 m.a.s.1.). Specimens of insects in the adult stage were collected at the end of the harvesting season, in November 2016, and examined under a stereoscopic microscope. Species were identified on the basis of descriptions provided in the literature (DeLong and Freytag 1964). Voucher specimens were deposited in the Insect Collection of the Biology Laboratory at the Campus Universitário da Região dos Vinhedos (CARVI), Universidade de Caxias do Sul (UCS), Caxias do Sul, RS, Brazil.

\section{RESULTS AND DISCUSSION}

Adult leafhoppers were identified as Gypona cerea DeLong \& Fretay, 1962 (De Long and Freytag,
1964). Specimens, which have approximately 10 $\mathrm{mm}$ in length, exhibited sexual dimorphism in that the males are reddish-brown while the females are light green (Fig. 1). Large quantities of eggs were found deposited on leaf veins and the branches of inflorescences (Araújo 2015), while nymphs and adults were present on inflorescences and new shoots. The leafhopper presents an upsidedown feeding habit because feeding locations were primarily at junctions between the main and secondary branches, in inflorescences or at the intersections of leaf petioles with the branches of new shoots (Araújo 2015).

At high levels of infestation, the inflorescences became covered with large amounts of sticky exudates (known locally as "mela") that can promote the growth of sooty mold, and the shoots and inflorescences commenced yellowing and eventually dried out (Figs. 2-4). In addition to direct damage, such as deformation and lesions, caused by sap suction, the leafhoppers can inoculate toxic substances and transmit viral and bacterial infections during feeding (Azevedo-Filho and Carvalho 2001, Giustolin et al. 2009). The resultant damage impedes the development of fruits and can cause significant economical losses.

In order to establish the level of crop infestation, it is recommended to examine one panicle on each of 45 plants selected at random per 15 ha of cultivated area. For larger areas, it is suggested to subdivide the plot in uniform parcels of 15 ha each and proceed as described above. The level of infestation is then expressed as the percentage of examined branches that were found to be infested (Araújo 2015).

The occurrence of Gypona sp. in cashew trees grown in Piauí was first reported in 1994 (Bleicher et al. 1994) and the insect was categorized as a pest in the same year. The recent observations described herein confirm that the insect is still present in the State. However, details of the biology and ecology of the insect have not been fully elucidated and the 


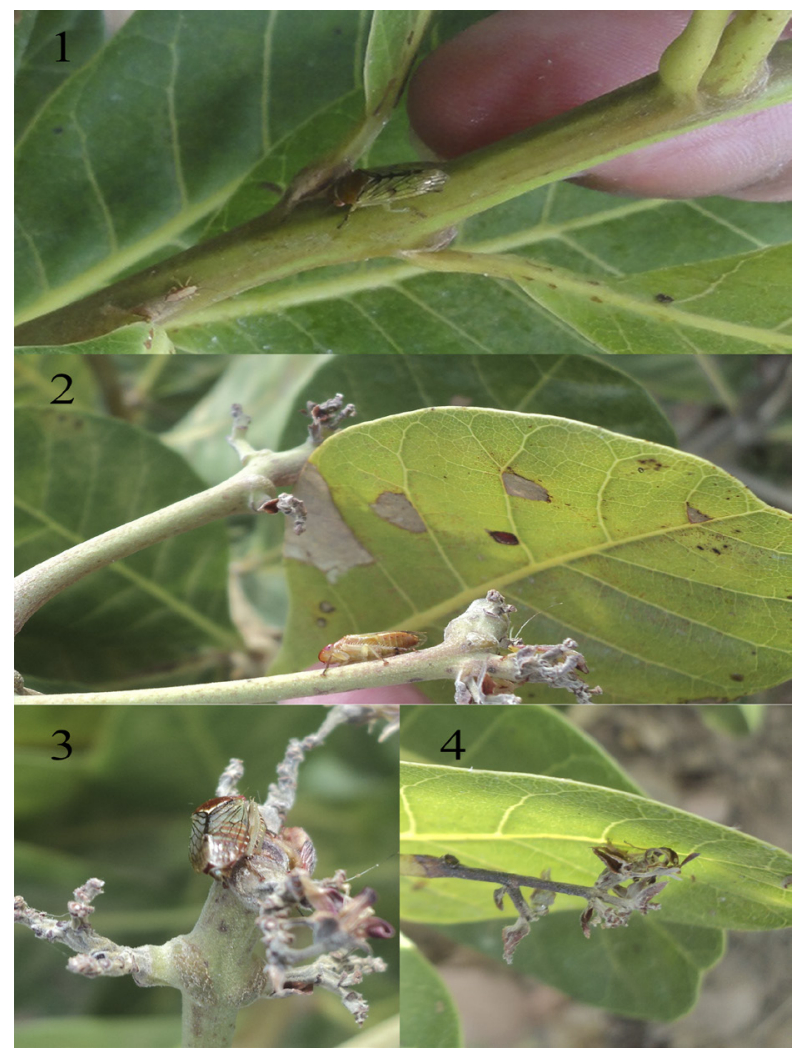

Figure 1-4 - (1) Female specimen of Gypona cerea feeding on a dwarf cashew tree in Canto do Buriti, PI, Brazil (Source: Vidal Neto FC); (2) Damage caused by Gypona cerea infesting a crop of dwarf cashew in Canto do Buriti, PI, Brazil; (3) Male of Gypona cerea feeding on a yellowing branch and an inflorescence showing symptoms of drying; (4) Totally dried out panicles. (Source: Serrano LAL).

data available are insufficient to determine if the insect population in the region is under control. Under these circumstances, cashew crops remain vulnerable to new outbreaks of infestation by the leafhopper.

Our study represents an important step towards the documentation of the occurrence of Gypona cerea in Piauí, knowledge that is essential in establishing trends in range expansion and in devising control strategies.

\section{AUTHOR CONTRIBUTIONS}

Souza SA - developed the research project. DiasPini NS - developed the research project. Serrano,
LAL - text writing, insect collection. Vidal Neto, FC - text writing, insect collection. Maciel, GPS - developed the research project. Sousa, VR text writing and images. Azevedo-Filho, WS identification.

\section{REFERENCES}

ARAÚJO JPP. 2015. Caju: o produtor pergunta, a Embrapa responde. Fortaleza: Embrapa Agroindústria Tropical, 250 p.

AZEVEDO FILHO WS AND CARVALHO GS. 2001 Giponíneos (Hemiptera, Cicadellidae) associados à cultura de Citrus sinensis (L.) Osbeck no Rio Grande do Sul, Brasil: I - Sordana e Reticana. Biociências 9(1): 121-139.

BLEICHER E, FURTADO IP AND MELO QMS. 1994. A cigarrinha-da-inflorescência do cajueiro. Boletim de Pesquisa e Desenvolvimento, Fortaleza: Embrapa Agroindústria Tropical. 9, $15 \mathrm{p}$.

DELONG DM AND FREYTAG PH. 1964. Four genera of the world Gyponinae: A synopsis of the genera Gypona, Gyponana, Rugosana and Reticana. Bull Ohio Biol Surv 2(3): 1-227.

GIUSTOLIN TA, LOPES JRS, QUERINO RB, CAVICHIOLI RR, ZANOL K, AZEVEDO FILHO WS AND MENDES MA. 2009. Diversidade de Hemiptera Auchenorrhyncha em citros, café e fragmento de floresta nativa do Estado de São Paulo. Neotrop Entomol 38(6): 834-841.

HARRIS KF AND MARAMOROSCH K. 1980. Vectors of plant pathogens. New York: Academic Press, 467 p.

IBGE - INSTITUTO BRASILEIRO DE GEOGRAFIA E ESTATÍSTICA. 2016. Produção agrícola municipal. [Internet] December. Available from: http://www.sidra. ibge.gov.br/pesquisa/pam.

MARAMOROSCH K AND HARRIS KF. 1981. Plant diseases and vectors: Ecology and epidemiology. New York: Academic Press, 368 p.

MARQUES RV. 2011. Cigarrinhas (Hemiptera: Cicadellidae) potenciais vetoras de um fitoplasma (grupo 16SrlX) associado a sintomas de huanglongbing dos citros, suas plantas hospedeiras e quantificação do patógeno [Tese de Doutorado]. Piracicaba: Escola Superior de Agricultura Luiz de Queiroz, Universidade de São Paulo, p. 86. Available from: http://www.teses.usp.br/teses/ disponiveis/11/11146/tde-02052011-092707/pt-br.php.

MARUCCI RC, CAVICHIOLI RR AND ZUCCHI RA. 2002. Espécies de cigarrinhas (Hemiptera, Cicadellidae, Cicadellinae) em pomares de citros da região de Bebedouro, SP, com descrição de uma espécie nova de Acrogonia Stål. Rev Bras Entomol 46(2): 149-164.

NIELSON MW. 1968. The leafhopper vectors of phytopathogenic viruses (Homoptera, Cicadellidae). 
Taxonomy, biology, and virus transmission. 2016. Tech Bull US Dep Agric 1382: 1-386. Available from: https:// naldc.nal.usda.gov/nalde/download.xhtml?id=CAT87201 $370 \&$ content $=$ PD.

NIELSON MW. 1985. Leafhopper systematics. In: Nault LR and Rodrigues JG (Eds), The leafhoppers and planthoppers. New York: Wiley-Interscience, 11-40 p.

NIELSON MW AND KNIGHT WJ. 2000. Distributional patterns and possible origin of leafhoppers (Homoptera, Cicadellidae). Rev Bras Zool 17 (1): 81-156.

PAIVA JR, BARROS LM AND CAVALCANTI JJV. 2009. Cashew (Anacardium occidentale L.) Breeding: a global perspective. In: Jain M and Priyadarshan PM (Eds),
Breeding plantation tree crops: tropical species. New York: Springer Verlag, 287-322 p.

SERRANO LAL AND OLIVEIRA VH. 2013. Aspectos botânicos, fenologia e manejo da cultura do cajueiro. In: Araújo JPP (Ed), Agronegócio caju: práticas e inovações. Brasília: Embrapa Informação Tecnológica, 77-165 p.

TRIPLEHORN CA AND JOHNSON NF. 2011. Estudo dos insetos - $2^{\mathrm{a}}$ edição brasileira. São Paulo: Cengage Learning, $809 \mathrm{p}$.

VIDAL NETO FC, BARROS LM, CAVALCANTI JJV AND MELO DS. 2013. Melhoramento genético e cultivares de cajueiro. In: Araújo JPP (Ed), Agronegócio caju: práticas e inovações. Brasília: Embrapa Informação Tecnológica, 481-508 p. 